\title{
Ethnobotany in the Folksongs of Castilla y León (Spain)
}

\author{
Baudilio Herrero ${ }^{1}$ y Mario Cardaño \\ Departamento de Ciencias Agroforestales, Universidad de Valladolid, Palencia, España \\ 'Corresponding author: baudilio@agro.uva.es
}

\begin{abstract}
In this study we present the results of analyzing 7,012 traditional songs from Castilla y León, compiled in songbooks published between the years 1931 and 2008. Thirty-three publications were reviewed. Plant species were mentioned in 18.7\% of the songs listed, which corresponds to 1,316 songs. On average, 2.1 plants were mentioned in each song. $59 \%$ of the songs only mentioned one plant species. A total of 2,756 botanical citations were recorded. The total number of plant species mentioned was 150 , corresponding to 46 plant families. The most mentioned plants were: rose (12.7\%), grape (7.1\%), carnation $(6.3 \%)$, wheat $(5.1 \%)$, olive $(4.1 \%)$, laurel $(2.8 \%)$, apple $(2.6 \%)$, pine $(2.6 \%)$, and orange $(2.3 \%)$. The families with the highest number of citations were: Rosaceae, Poaceae, Vitaceae, and Caryophyllaceae. Of all the plant citations in this study of the folk songs of Castilla y León, 55\% relate to plants that are cultivated. Of all the songs, $76.1 \%$ were categorized into a musical genre and 1,853 plant citations were registered in these songs. The largest numbers of botanical quotes were found in the songs of dancing, marriage, serenade, and romance. The songs of supplication most frequently cited the Poaceae; and Christmas songs, the Rosaceae. About the botanical citations, $33.6 \%$ refer to the symbolic value of the plants. In $50.7 \%$ of cases, the symbolism alluded to beauty, and in $6.9 \%$ of cases, a love proposition. The plants used most frequently to symbolize beauty were the rose and the carnation. The romantic proposal was often represented by the rose and laurel. The higher social class was symbolized by wheat, flax, and walnut. The lower social class was linked to quotes about rye or legumes.
\end{abstract}

Key words: ethnomusicology, folk, musical genre, plants, symbology.

Resumen: En este trabajo se presentan los resultados de analizar 7,012 canciones tradicionales de Castilla y León, recopiladas en cancioneros publicados entre los años 1931-2008. Se han revisado 33 publicaciones. El 18.7\% de las canciones mencionan especies vegetales, lo que corresponde a 1316 canciones. En cada canción se menciona una media de 2.1 plantas. El 59\% de las canciones solo menciona una especie vegetal. Se han contabilizado un total de 2756 citas botánicas. El total de especies vegetales mencionadas ascendió a 150, que corresponden a 46 familias botánicas. Las plantas más mencionadas son: rosa (12.7\%), vid (7.1\%), clavel (6.3\%), trigo (5.1\%), olivo (4.1\%), laurel (2.8\%), manzano (2.6\%), pino (2.6\%) y naranjo (2.3\%). Las familias que presentan mayor número de citas son: Rosaceae, Poaceae, Vitaceae y Caryophyllaceae. El 55\% de las citas vegetales se relacionan con plantas que constituyen cultivos. El 76.1\% de las canciones fueron catalogadas en algún género musical, de las cuales se recogieron 1853 citas vegetales. El mayor número de citas botánicas se recogen en los cantos de baile, boda, serenata y romance. Los cantos de rogativa citan con mayor frecuencia las Poáceas; y en las canciones de navidad, las Rosáceas. El 33.6\% de las citas botánicas aluden al valor simbólico de las plantas. En el 50.7\% de los casos, la simbología hizo alusión a la belleza y el 6.9\% a una proposición amorosa. Las plantas que simbolizan la belleza con más frecuencia son la rosa y el clavel. La propuesta amorosa se simboliza frecuentemente con rosa y laurel. La clase social alta está simbolizada por trigo, lino y nogal. La clase social baja vinculada a citas sobre centeno o legumbres.

Palabras clave: etnomusicología, género musical, música tradicional, plantas, simbología.

$\mathbf{E}$ thnobotany is the science that describes the relationship between humans and plants but the factors that influence that relationship are not well defined. The interdisciplinary approach is well known in ethnobotany (Etkin and Elisabetsky, 2005) and can help us to understand what factors may interact and have a decisive influence on the selection of plants used by humans (Akerreta et al., 2007).

Ethnobotany is an integrative, multi-disciplinary field of learning. Thus, the tools of ethnobotanical investigations are many: botany, mycology, taxonomy, anthropology, ethnography, archaeology, comparative folklore, religious studies, medicine, chemistry, pharmacology, and more. Sometimes, in ethnobotanical inquiry, we call upon ancient history, or colonial socio-economic histories, or we even examine the roots of our modern social movements.

Music is an exciting and intangible art form. Ancient sa- 
ges and philosophers from Egypt, India, and Greece, knew that music is sound, and that sound is a transformative force on several levels. The sound of music was believed to be ultimately capable even of creating and reshaping matter itself. This was because audible sound, including music, was considered to be an outpouring of a higher or cosmic sound, which is the source of all energy/matter (Holman, 2002).

One of the many branches of investigation that draw on cultural knowledge, and that begin with the prefix 'ethno', is Ethnomusicology, the study of the music of different cultures, and the musical instruments they make and use, which are often made of plant materials. Ethnomusicology may include the study of dance. Songs are traditional anonymous poetry often created by an anonymous author who ends up being accepted by a community (Alín, 1991). Generally this poetry is not popular in its origin, but the songs are the result of the work of a poet.

The use of plants to produce musical instruments has been addressed in several studies (Puri and Chaturvedi, 2008; Keller, 2010). Studies on plants in musical compositions are scarce; as examples are the studies of plants in a Christmas carol (Francés and Rodríguez, 2009) and in songbooks (Cardaño and Herrero, 2014). References to plants in significant texts such as the Bible and works of Cervantes have been analyzed (Moldenke and Moldenke, 2002; Pardo-de-Santayana et al., 2006). The aim of this paper was to highlight the importance of plants in cultural manifestations such as music, to determine which plants form part of the musical stanzas, to establish relationships between the plants and the different musical genres and to indicate the symbology of the plants cited in the songs.

\section{Material and methods}

We analyzed the folksongs contained in all popular songbooks we could locate in the study region: the regional context of Castilla y León. In order to obtain the material, the following sources were consulted: the library archives of the Faculty of Arts at the University of Valladolid, the provincial archive of Palencia, the Joaquín Díaz Foundation Library in Urueña (Valladolid), the Network of Libraries of Castilla y León, and document search on the Internet.

The various songs compiled in the songbooks were reviewed one by one, recording the following details: town, province, song title, song type, time of year represented, the fragment of the song where plant species appears, and the context. With this information, we performed a database that have been arranged in the following fields: the common name of the plant which is mentioned, the number of times it is cited in a song, the symbolic value attributed to the plant and other data such as the variety, ecosystem, and ecology.

To relate the common name with the scientific name, a number of publications were used (Ceballos, 1986; Sán-
chez-Monge, 1991; Morales et al., 1996). In the case of common names that relate to various botanical species, we chose to assign the most common plant in the region, and in some cases we chose to associate the common name with a scientific genus since we were not able to add further detail. Hereafter, we will use the term "species", understanding that in some cases we also speak of several species of one genus.

If the same song appeared in several locations, the songs were merged into one record. When the folklorist has not assigned a song type, this field has been left blank because, although some songs share the same verses, this does not mean they are the same in their interpretation or structure.

Area of study. Castilla y León spans a total surface of $94,147 \mathrm{~km}^{2}$. It is situated in the northern Iberian Peninsula, in south-west Europe. It is a scarcely populated territory, it presents 2.6 million inhabitants living in rural settlements. It is therefore, a rural society, whose economy is maintained by agriculture and natural resources.

Castilla y León is an inland region. Its climate has rainfall which is distributed irregularly and drought during the summer, corresponding to the Mediterranean climate. However, the geographical features of the region add a continental nuance, where a Mediterranean forest develops, dominated by Quercus ilex and $Q$. faginea. In northern outlying mountainous areas, there is an Atlantic climate and at the highest elevation it turns into alpine. In these conditions an Atlantic forest develops, dominated by Fagus sylvatica and $Q$. pyrenaica (Junta de Castilla y León, 1992). Rainfalls range from 400 to $1,500 \mathrm{~mm} \mathrm{year}^{-1}$. $37.3 \%$ of the land is devoted to crops (particularly barley, wheat, and oats) and $30.2 \%$ is covered by woodland (Cardaño, 2009).

It is one of the largest regions in Europe and has one of the highest densities of cultural heritage, with attractive cathedrals, churches, and castles from Middle Ages and Modernity, as well as varied natural expanses. Due to its, central location and contact with several surrounding regions, Castilla y León has adopted diverse musical influences throughout its history, which is reflected in an extraordinary range of folk music. Simplicity and lack of frills are its hallmark. The most widespread rhythms are the jota, fandango, and circle dances.

\section{Results}

Thirty-three publications were found and reviewed. These works are listed in appendix 1. Of the 7,012 analyzed songs, 1,316 mentioned plants in their verses. These songs contained references to 2,756 plant species. The songs comprised mostly anonymous poetry, created from the seventeenth to the twentieth century, which was popularized and preserved by oral tradition to the present day (Alín, 1991). Most songs $(83 \%)$ do not contain mentions of plants. 


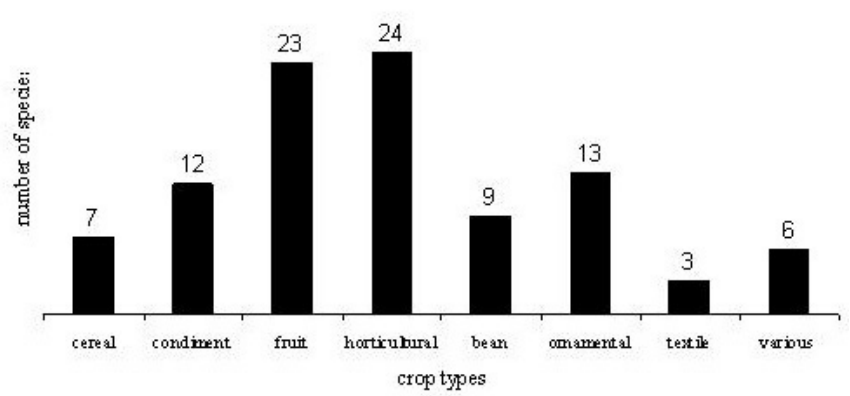

Figure 1. The distribution of quotations alluding to cultivated plants, according to the plant type.

Appendix 2 summarized the 150 plants species mentioned in the songs. Also is indicated the family name, the common name that is mentioned in the musical works, and the status of presence of each in the region. Fifty-five species had more than ten citations, and another 95 plants had fewer than ten. The most mentioned plants were rose, grape, carnation, wheat, and olive.

The distribution of cultivated plants in different crop categories is given in figure 1 . Of the 150 species, 65 were cultivated, with fruit and vegetable crops accounting for $43 \%$ of the citations registered. The species that contribute most to these results are the grape and the olive, amongst the fruit species, and the pumpkin and the pepper amongst the vegetables. References are made with 58 wild species, which constitute $38.6 \%$ of the plants mentioned, 15 species are absent (they are not represented in the region), the rest, 12 species are decorative (they only appear in gardens, plant pots, or bouquets of flowers). In relation to the number of citations, cultivated plants make up more than half of the citations $(55.1 \%$ ), followed by decorative species $23.5 \%$, wild plants $18.2 \%$, and absent species which amount to $3.2 \%$ of the citations.

About the 1,316 songs that mention plants, $76 \%$ could be assigned to a musical genre (Figure 2), and it becomes clear that the song types dancing, marriage, children, rounds, and romances are the ones in which mention of plants are most common. $70.4 \%$ of the citations were collected in these five song genres. The category "various" included the following types of song: morning, carnival, bulls, and picaresque.

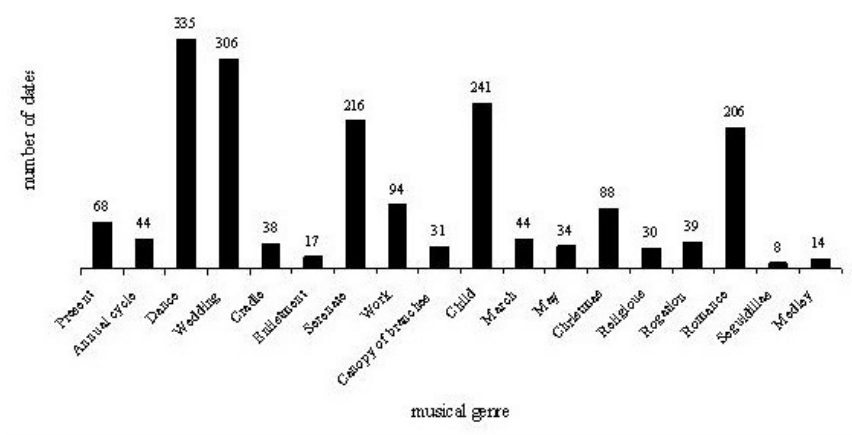

Figure 2. The number of plant citations distributed by musical genre.
Table 1 shows the 42 plants which accumulated 11 or more citations in the songs of the 17 most frequent musical genres, as well as a data column which grouped together the citations of carnival, dawn, bulls, and picaresque songs. The list of plants comprised 132 species, with a total of 1,853 citations. The presence of plants was most evident in songs of dancing, marriage, and children, that is related to fertility and reproduction. In these three song types, the rose had the highest number of citations, followed by the carnation and the grape. In wedding songs, walnut, flax and parsley are added to this list. For songs that are rounds, carnation, rose, grape, and olive are again common, but the pine is also added. In work songs the Poaceae stands out along with the grape and Fabaceae. In songs related to the canopy of branches, the carnation and the rose are mentioned, but reference is made also to laurel, rosemary, and apricot. Children songs incorporate references to Rutaceae and Cucurbitaceae. March songs hint at the end of the agricultural work related to sowing seeds, and the most relevant species are barley and grapes. In the songs of supplication, the Poaceae are the most mentioned; barley is the most significant crop in this region, and the one which creates the most concern regarding the outcome of its harvest. The romance represents the song type with the fifth most botanical quotes, mentioning carnation, rose, olive, vine, lily, and barley. Christmas bonus songs, in which young people ask for money or food, are sung at Christmas time, and the most mentioned species in this genre are wheat and grapes. Of the songs about the yearly cycle, those sung in autumn mention the olive very frequently, and reference is made to the collection of this fruit in the autumn. In spring, the carnation and rose are mentioned frequently.

The rose, carnation, grape, wheat, and olive are the plants with the highest number of mentions regardless of the musical genre. The greatest diversity of plants cited corresponds to the genre of dance songs, which contained 76 species.

A total of 926 citations were registered as symbolic value, i.e., $33.6 \%$ of the citations found referred to the symbolic value of the plants. The plants that have the highest number of items referring to symbolism are the rose, carnation, grape, flax, wheat, and laurel. The symbolism was divided

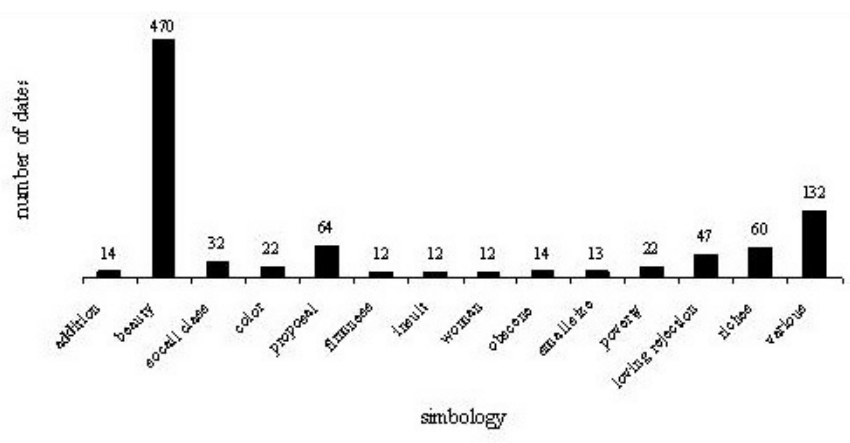

Figure 3. The number of plant citations distributed according to the category of symbolism represented. 


\section{Baudilio Herrero y Mario Cardaño}

Table 1. Plants that have 11 or more citations, and the distribution of references according to song type.

\begin{tabular}{|c|c|c|c|c|c|c|c|c|c|c|c|c|c|c|c|c|c|c|c|}
\hline Scientific name & 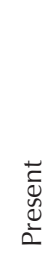 & $\begin{array}{l}\frac{U}{U} \\
\frac{U}{U} \\
\frac{\widetilde{J}}{\partial} \\
\frac{\partial}{2}\end{array}$ & 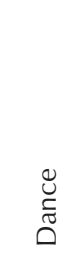 & 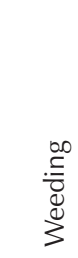 & $\frac{\stackrel{0}{\bar{\sigma}}}{\stackrel{\Xi}{U}}$ & 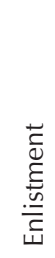 & $\begin{array}{l}\frac{0}{0} \\
\frac{\pi}{0} \\
\frac{0}{d} \\
\mathscr{N}\end{array}$ & $\frac{\text { ㅎ }}{3}$ & 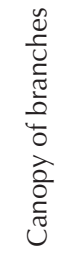 & $\frac{\bar{O}}{\bar{U}}$ & 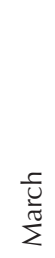 & $\stackrel{\widehat{\pi}}{\boldsymbol{J}^{2}}$ & 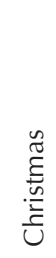 & 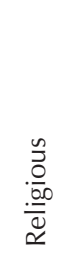 & 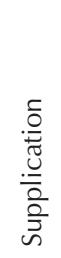 & 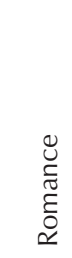 & 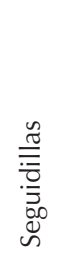 & $\frac{\stackrel{n}{\sigma}}{\frac{0}{n}}$ & 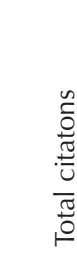 \\
\hline Allium sativum & 2 & & 3 & & & & 1 & & & 4 & & & 1 & & & 3 & & & 14 \\
\hline Capsicum annuum & 2 & & 2 & & 1 & 2 & & & & 3 & & & 3 & & & & 1 & & 14 \\
\hline Castanea sativa & 5 & & 2 & 1 & & & & & 1 & 5 & 1 & & 2 & & & 1 & & & 18 \\
\hline Citrus limon & 1 & & 12 & 1 & 2 & & 4 & & & 13 & 3 & & & & & 4 & & 1 & 41 \\
\hline Citrus sinensis & & 1 & 14 & 3 & 1 & & & 1 & & 10 & 3 & 2 & 2 & & 1 & 3 & & & 41 \\
\hline Corylus avellana & & 3 & 10 & 1 & & & 4 & 3 & 1 & 2 & & & 4 & & & & & & 28 \\
\hline Crataegus monogyna & 1 & & 6 & 5 & & & 1 & 1 & & 1 & & & & & & 1 & & & 16 \\
\hline Cucumis melo & & & 3 & 1 & 1 & & & & & 5 & & & & & & 1 & & & 11 \\
\hline Cucurbita pepo & 1 & 1 & 9 & & & & 3 & 1 & & 2 & & & & & 1 & 4 & & & 22 \\
\hline Cytisus scoparius & & 1 & 1 & 4 & 1 & & 2 & 2 & & 2 & & & & & & 2 & & & 15 \\
\hline Dianthus caryophyllus & 2 & 3 & 16 & 25 & 5 & 2 & 22 & 1 & 2 & 13 & & 4 & 5 & 4 & & 9 & 3 & 1 & 117 \\
\hline Ficus carica & 3 & & 2 & 3 & & & 2 & & 1 & 5 & 1 & 1 & 3 & & & & & & 21 \\
\hline Hordeum vulgare & 3 & & 8 & 2 & & 1 & 2 & 3 & & 5 & 5 & 2 & & & 3 & 7 & & 1 & 42 \\
\hline Iris spp. & & & 3 & 11 & & & 3 & & & 3 & 1 & 1 & & 1 & & 7 & & & 30 \\
\hline Junglans regia & 1 & & 4 & 11 & & & 5 & & & 2 & 1 & & 5 & & & & & & 29 \\
\hline Lactuca sativa & & & 6 & 1 & 1 & & 5 & 2 & & 4 & & & & & & 1 & & & 20 \\
\hline Laurus nobilis & 2 & & 10 & 6 & & 1 & 8 & 3 & 3 & 3 & & & 3 & 1 & & 2 & 1 & & 43 \\
\hline Lilium candidum & 1 & & 2 & 5 & & & 2 & & & 3 & & 3 & 2 & 2 & 2 & 5 & & & 27 \\
\hline Linum usitattisimun & & & & 9 & & & & 2 & & 2 & 1 & 1 & & & & 6 & & 1 & 22 \\
\hline Malus domestica & 2 & & 9 & 8 & 4 & & 7 & & & 10 & 2 & & 9 & & & 2 & & & 53 \\
\hline Mentha spicata & & & 2 & 2 & & & 3 & 3 & 1 & & & & 1 & & 2 & 1 & & 1 & 16 \\
\hline Nicotiana tabacum & 1 & & 2 & 3 & & 1 & 2 & & & 4 & & & & & & 3 & & & 16 \\
\hline Olea europaea & 2 & 18 & 10 & 14 & & & 12 & 6 & 1 & 4 & & 1 & 3 & & & 14 & & & 85 \\
\hline Petroselinum crispum & & & 10 & 12 & 2 & & 1 & & 1 & 2 & & & 1 & & & & & 2 & 31 \\
\hline Phoenix dactylifera & 1 & & 1 & 5 & & & & & & & & 1 & 1 & 1 & & 2 & & & 12 \\
\hline Pinus spp. & 3 & 2 & 11 & 6 & & 1 & 8 & 1 & 1 & 3 & & 2 & 1 & & & 7 & & & 46 \\
\hline Piper nigrum & & & 3 & 1 & & & 3 & & & 2 & & & 1 & & & 1 & & & 11 \\
\hline Populus spp. & & & 6 & & & & 4 & 1 & 2 & 7 & & & & & & 1 & & & 21 \\
\hline Prunus avium & & 1 & 2 & & & & 1 & 1 & 1 & 4 & & & & & & 1 & & & 12 \\
\hline Prunus dulcis & 1 & & 3 & 3 & & & 2 & 1 & 1 & 4 & & & 1 & & & 3 & & & 19 \\
\hline Pyrus communis & 3 & & 11 & & & & 2 & 3 & 1 & 5 & 1 & & 2 & & & 4 & & & 32 \\
\hline Quercus ilex & & & 6 & 5 & & & 1 & 1 & & 2 & & & & & & 2 & & & 17 \\
\hline Rosa spp. & 2 & 5 & 36 & 53 & 11 & 2 & 50 & 2 & 4 & 20 & 3 & 6 & 10 & 4 & 1 & 33 & 1 & & 244 \\
\hline Rosmarinus officinalis & & & 6 & 9 & 1 & & 6 & 1 & 2 & 3 & & & 5 & 3 & & 2 & & & 38 \\
\hline Rubus ulmifolius & 1 & & 3 & 3 & 1 & 1 & 3 & & & 1 & & & 1 & & 1 & 4 & & & 19 \\
\hline Secale cereale & 2 & & 2 & 8 & & & & 3 & & & & & & & 1 & 1 & & & 17 \\
\hline Solanum tuberosum & & & 2 & 1 & & & 1 & 3 & & 6 & & & & & & & & & 13 \\
\hline Theobroma сасаo & & & 2 & 3 & & & 1 & & & 5 & & & & & & & & & 11 \\
\hline Thymus spp. & & 1 & 2 & 4 & & & & 2 & & & & & 2 & 3 & 3 & & & & 17 \\
\hline Triticum spp. & 5 & & 14 & 16 & & 2 & 5 & 8 & 2 & 6 & 2 & 3 & 3 & 2 & 16 & 16 & & & 100 \\
\hline Vicia faba & & & 3 & 1 & & & & 2 & & 4 & & 1 & 1 & 1 & & 1 & & & 14 \\
\hline Vitis vinifera & 11 & 3 & 20 & 23 & 1 & 2 & 13 & 13 & 1 & 9 & 7 & & 4 & & 4 & 26 & & 2 & 139 \\
\hline Sum & 58 & 39 & 270 & 269 & 32 & 15 & 189 & 70 & 26 & 188 & 31 & 28 & 76 & 22 & 35 & 180 & 6 & 9 & 1543 \\
\hline Total species & 32 & 16 & 76 & 59 & 18 & 12 & 55 & 45 & 22 & 61 & 22 & 19 & 36 & 17 & 14 & 56 & 6 & 12 & 132 \\
\hline
\end{tabular}


Table 2. Plants reaching 4 or more citations, and the distribution of references among the symbolism categories.

\begin{tabular}{|c|c|c|c|c|c|c|c|c|c|c|c|c|c|c|c|}
\hline Scientific name & 兮 & 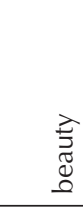 & 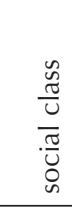 & $\frac{\overline{0}}{0}$ & $\begin{array}{l}\overline{0} \\
0 \\
0 \\
0 \\
0 \\
0\end{array}$ & 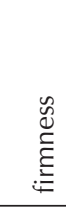 & $\begin{array}{l}\frac{ \pm}{5} \\
. \subseteq \\
.\end{array}$ & $\begin{array}{l}\text { ฮ } \\
\text { है } \\
\vdots\end{array}$ & 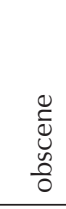 & $\frac{\stackrel{N}{N}}{\frac{\bar{N}}{\tilde{E}}}$ & $\begin{array}{l}\overrightarrow{2} \\
\frac{\overrightarrow{0}}{2} \\
\stackrel{2}{2}\end{array}$ & 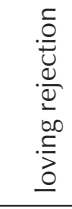 & $\frac{\mathscr{U}}{\underline{U}}$ & 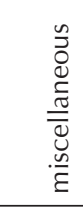 & $\frac{\mathscr{0}}{\frac{\pi}{0}}$ \\
\hline Capsicum annuum & & 7 & & & & & & & & & & & & 1 & 8 \\
\hline Citrus limon & & & 1 & 2 & 6 & & & 1 & & & & 3 & 4 & 6 & 23 \\
\hline Citrus sinensis & & 6 & & & 4 & & & & & & & & 4 & 4 & 18 \\
\hline Corylus avellana & & 2 & & 1 & & & & & & & & 4 & & 1 & 8 \\
\hline Crataegus monogyna & & & & 1 & & & & & & & & & & 3 & 4 \\
\hline Cuburbita pepo & & 2 & & & & & & & & & & 29 & & & 31 \\
\hline Cucumis sativus & & & & & & & 1 & 3 & & & & & & & 4 \\
\hline Cytisus scoparius & & 2 & & & 1 & & & & & & 2 & & & 2 & 6 \\
\hline Dianthus caryophyllus & & 89 & 1 & & 8 & & & 1 & & & & & 2 & 6 & 107 \\
\hline Ficus carica & & 1 & & & 1 & & 1 & & & 1 & & & & 3 & 7 \\
\hline Hedera helix & & & & & & & & & 1 & & & & & 5 & 6 \\
\hline Hordeum vulgare & & 4 & & & & & & & & 2 & 1 & & 2 & 1 & 10 \\
\hline Iris spp. & & 16 & & & & & & & & & & & & 4 & 20 \\
\hline Jasminum spp. & & 5 & & & & & & & & & & & & & 5 \\
\hline Junglans regia & & & 2 & & 1 & & & & & & & & 5 & 3 & 11 \\
\hline Lactuca sativa & & 8 & 1 & & & & 3 & & & & & 1 & & & 13 \\
\hline Laurus nobilis & & 11 & & & 9 & 7 & & 1 & & & & & & 2 & 30 \\
\hline Lilium candidum & & 30 & & & 1 & & & & & & & & & 2 & 33 \\
\hline Linum usitatissimun & & & 2 & & & & & & & & & & 8 & & 10 \\
\hline Malus domestica & & 6 & & 4 & 3 & & 2 & 2 & & & & & & 6 & 23 \\
\hline Olea europea & & 5 & & & & & & & 2 & & & 1 & 6 & 6 & 20 \\
\hline Papaver rhoeas & & 3 & & & 1 & & & & & & 1 & & & & 5 \\
\hline Petroselinum crispum & & 1 & 1 & 2 & & & & & 2 & & & & 1 & 1 & 8 \\
\hline Phoenix dactylifera & & 5 & & & & & & & & & & & & & 5 \\
\hline Pinus spp. & & 7 & & & 5 & 2 & & & 1 & & 1 & & 5 & 4 & 25 \\
\hline Piper nigrum & & 1 & & & & & & 1 & & 4 & & & 1 & & 7 \\
\hline Populus spp. & & & & & 1 & 3 & & & & & & 2 & & 3 & 9 \\
\hline Prunus dulcis & & 5 & & & & & & & & & & & 1 & 1 & 7 \\
\hline Prunus persica & & & & 2 & & & & & & & & 3 & & & 5 \\
\hline Punus avium & & & & 1 & & & & & & & & 1 & 1 & 1 & 4 \\
\hline Pyrus communis & & 3 & & & 1 & & 2 & & & & & & & 2 & 8 \\
\hline Quercus spp. & & 1 & & & & & 2 & & & & 3 & & & 1 & 7 \\
\hline Rosa spp. & & 199 & 3 & 5 & 17 & & & 5 & & & & & 1 & 11 & 241 \\
\hline Rosmarinus officinalis & & 8 & & & 1 & & & 1 & & & & & 1 & 3 & 14 \\
\hline Rubus ulmifolius & & 1 & 1 & & & & & & & & & & & 6 & 8 \\
\hline Secale cereale & & 2 & 7 & & & & & & & & 4 & & & & 13 \\
\hline Thymus spp. & & 4 & & & & & & & 1 & 1 & & & & 5 & 11 \\
\hline Triticum spp. & & 4 & 7 & 1 & & & & & & 4 & 1 & & 9 & 5 & 31 \\
\hline Vitis vinifera & 14 & 2 & 2 & & 2 & & & & & & & & 2 & 11 & 33 \\
\hline Sum & 14 & 440 & 28 & 19 & 62 & 12 & 11 & 12 & 7 & 12 & 13 & 44 & 53 & 109 & 836 \\
\hline Total species & 1 & 51 & 15 & 13 & 18 & 3 & 7 & 7 & 10 & 6 & 16 & 11 & 23 & 46 & 91 \\
\hline
\end{tabular}

into 24 categories. Figure 3 shows the symbolic value of the plants distributed into the most common 13 categories. In the "miscellaneous" column, eight categories have been combined because had a few botanical citations. The most common concept symbolized, in $50.7 \%$ of the citations, was beauty; the species mentioned most commonly being the rose, which embodies feminine beauty, and the carnation, masculine beauty. Addiction is symbolized by the grape, and frequently alludes to the problems that come with its excessive consumption. The declaration of love is represen- 
ted by a greater diversity of plants, 18 species being mentioned in this regard. The rose, carnation, laurel, and lemon all stand out with regards to declarations of love.

Table 2 presents 39 species that reach four or more citations, which allude to the symbolic value of the plants in the context of the musical stanzas, divided into 13 categories. The "miscellaneous" column includes citations alluding to mood states (sadness, disappointment), human qualities (courage, stupidity), seasons, or bad habits. A total of 91 $(60.7 \%)$ genera-species were related to symbology.

Higher social class is associated with wheat, whereas rye symbolizes lower class. The red color of roses and apples is also referred to frequently in the verses of the songs. The strength of a promise is symbolized by the laurel. The sma11 size of the grains of cereals and pepper symbolizes size. The cucumber stands out as an obscene symbol. Poverty and wealth are symbolized as follows: cereals, flax, olive, and walnut for wealth, in contrast with Fabaceae and reeds for poverty. Rejection in love is symbolized with Cucurbitaceae, especially the pumpkin.

In addition, we have found information on characteristics of the habitat or the ecosystem of the plants. Aspects of the ecology of plants are described in 234 citations. Examples include the fact that the water must be cold for the harvest of good watercress and that dark brown soil is suitable for growing wheat, barley, and oats. Finally, we note that 57 citations referred to varieties of certain crop species such as beans, pears, peppers, grapes, or Brassica oleracea.

\section{Discussion}

The number of plants is similar to that found by Pardo-deSantayana et al. (2006) in the work of a single author: Cervantes. In the case of the songbooks analyzed, despite the fact that the number of authors is greater, the number of plants mentioned has not increased. This may be due to the fact that the important plants for people were known by this author. The number of species mentioned in the songs was significantly low; in the case of texts about medicinal plants used traditionally in this region, 450 species have been registered (Herrero and Santos, 2009), indicating that medicinal plants are known more by healers who have more contact with nature than most of the poets that wrote the songs.

The high number of crop plants, their high percentage of citations, and the prominent role of botanical families of great agricultural interest reflect the importance of agriculture in the economy of the rural society in the area covered in this study. The importance of plants in the economy of rural societies is evident in cultural manifestations such as music, a fact also found in sculpture and painting (Fischer et al., 2011). Plants related to human consumption are mentioned the most; wheat is mentioned much more than barley, even though it occupies half of the acreage of the latter crop. Barley is mainly used in animal feed. The pepper, despite being introduced in the modern age, has become important in the eating habits of the people in the region, contributing flavors that are greatly appreciated in the regional cuisine and reflected in the musical compositions.

Wine, as a drink to accompany meals and recreational activities, is extremely prominent in the songs. Olive oil is the raw material that is missing in very few dishes, and other condiments, such as onion, garlic, and parsley, are also frequently mentioned in the songs, reflecting the importance of food in rural life.

Absent species in this work, such as frankincense, myrrh, tamarind, cinnamon, clove, palm, royal palm, bamboo, cocoa, and te, are cited in the songbooks analyzed, data matching those of Pardo-de-Santayana et al. (2006) in a study of ethnobotany in the works of Miguel de Cervantes, which attributes the mention of exotic species to the author's intention to make the literary text more attractive. These species come from faraway places and are associated with biblical events or in reference to the purchasing power of those that have certain spices at their disposal, possibly reminiscent of the ancient spice trade and travel to the Americas. Moldenke and Moldenke (2002) also highlighted as significant the exotic species found in the Bible.

It is curious that the Rutaceae family, with species such as orange, lemon, and lime, etc. whose presence in the community is low, has so many mentions. This family also has a significant importance in the work of Cervantes (Pardo-deSantayana et al., 2006). Taxaceae, Cupressaceae, and Cistaceae have very few citations despite the fact that they are known colloquially among the people, they are significant in size and their recognition is not difficult. Religious songs mentioned Labiatae, such as thyme, rosemary, and lavender, matching data with Brown (1985). The songs associated with the stages of life associated with fertility (romance, marriage, children) have high numbers of plant quotations; however, other types of songs, about fertility, for which a greater number of quotes would be expected due to their seasonality had few recorded cases: the songs of March, May, and work.

The symbolism of the rose as feminine beauty and the carnation as male beauty is also similar to the findings of other authors (Turner, 1988; Tompkins and Bird, 1994; Cleene and Leujene, 2002). In agreement with data reported by Domínguez (1941), the rose and the carnation are the two flowers that are most cited as a symbol of beauty, whereas the ivy had few symbolic citations, and the birch had none at all. Pinaceae are mentioned with relevance, coinciding with Domínguez (1941). Jiménez (1992) states that the species apricot and cherry indicate love; fig leaves, arbutus, and hawthorn express offense; and rejection in love is represented by the arbutus, pear, or hawthorn. The relationship of laurel with firmness and romantic declarations has also been highlighted by other authors (Rivera and Obón, 1991; FontQuer, 1995). The pumpkin is considered an anti-aphrodisiac 
from ancient Egypt, eloquently symbolizing romantic rejection or failure in a project.

\section{Conclusion}

Plants play a prominent role in the folk songs of Castilla y León, and are present in one fifth of the songs. The plants that are most mentioned are related to agricultural activities, showing the importance of this activity in the life of the rural society. The most frequently mentioned plants in the songs include the rose, grape, wheat, and carnation. The songs with the most plant citations were the genres dance, marriage, and the round. Similarly, the song genres with the greatest diversity of species were the dance, children, and marriage, those which is very significant stages in the cycle of life in rural society. The symbolic value that is most reflected by the plants in the musical verses is beauty and the declaration of love.

\section{Literature cited}

Akerreta S., Caver R.Y., López V. and Calvo M.I. 2007. Analyzing factors that influence the folk use and phytonomy of 18 medicinal plants in Navarra. Journal of Ethnobiology and Ethnomedicine 3:16.

Alín J.M. 1991. Cancionero Tradicional. Castalia, Madrid.

Brown C.H. 1985. Mode of subsistence and folk biological taxonmy. Current Anthropology 26:43-64.

Cardaño-Martínez M. 2009. Estudio Etnobotánico del Cancionero popular de Castilla y León. Trabajo de fin de Carrera, Ingeniería Técnica Agrícola, Universidad de Valladolid, Palencia. 131 pp.

Cardaño M. and Herrero B. 2014. Plants in the Songbooks of Castilla y León, Spain. Ethnobotany Research \& Applications 12:535-549.

Ceballos J.A. 1986. Diccionario iIustrado de los Nombres Vernáculos de las Plantas en España. Editorial ICONA, Madrid.

Cleene M. and Leujene M.C. 2002. Compendium of Symbolic and Ritual Plants in Europe. Man \& Culture Publishers, Ghent.

Domínguez B.M. 1941. Del Cancionero Leonés. Proa, León.

Etkin N.L. and Elisabetsky E. 2005. Seeking a trasdisciplinary and culturally germace science: the future of ethnopharmacology. Journal Ethnopharmacology 100:23-26.
Fischer L.P., Verilhac R., Ferrandis J.J. and Trépardoux F. 2011. Les plantes médicinales et symboliques dans les jardins mystiques des retables médiévaux. Histoire des Sciences Medicinales 45:295-301.

Font-Quer P. 1995. Plantas Medicinales. El Dioscórides Renovado. Editorial Labor, Barcelona.

Francés C.M.C. and Rodríguez T.F. 2009. Un villancico con numerosas plantas medicinales (Santa Fe de Bogotá, Colombia, ca. 1722). Anales Real Academia Nacional Farmacia 75:639-678.

Herrero B. and Santos L. 2009. Medicinal plants of traditional use in Castilla y León (Spain). Acta Horticulturae 826:229-236.

Holman E.W. 2002. The relation between folk and scientific classifications of plants and animals. Journal of Classification 19:131-159.

Jiménez J.E. 1992. Cancionero español, Candelada, Ávila. Manresa, Madrid.

Junta de Castilla y León. 1992. Análisis del Medio Físico de Castilla y León: Síntesis regional. Consejería de Medio Ambiente y Ordenación del Territorio, Valladolid.

Keller H.A. 2010. Plantas usadas por los guaraníes de misiones (Argentina) para la fabricación y el acondicionamiento de instrumentos musicales. Darwiniana 48:7-16.

Moldenke H.N. and Moldenke A.L. 2002. Plants of the Bible. Kegan Paul, London.

Morales R., Macía M.J., Dorda E. and García-Villaraco A. 1996. Nombres vulgares II. Archivos de Flora Ibérica 7:1-325.

Pardo-de-Santayana M., Tardío J., Heinrich M., Touwaide A. and Morales R. 2006. Plants in the work of Cervantes. Economic Botany 60:159-181.

Puri A.K. and Chaturvedi A. 2008. Ethnobotanical approach on wild plants for manufacturing musical intruments by Gond and Korku tribes of Vidarbha. Indian Journal of Traditional Knowledge 7:138-140.

Rivera N.D. and Obón C.C. 1991. La Guía Incafo de las Plantas Útiles y Venenosas de la Península Ibérica y Baleares (excluidas medicinales). Incafo, Madrid.

Sánchez-Monge P.E. 1991. Flora Agrícola. Tomos I y II. Ministerio de Agricultura, Pesca y Alimentación, Madrid.

Tompkins P. and Bird C. 1994. The Secret Life of Plants. Harper \& Row, New York.

Turner N.J. 1988. "The importance of Rose": evaluating the cultural significance of plants in Thompson and Lilloet Interior Salish. American Anthropologist 90:272-290. 
Appendix 1. Musical works analyzed.

Blanco González A. 1995. Palabras contra el tiempo. Tradición oral en Peñafiel y pueblos adyacentes. Calatrava, Valladolid. Caja Segovia. 2003. De la tierra: canciones y romances segovianos de ayer y hoy. Caja Segovia, Segovia.

Carril Ramos A. and Manzano Alonso M. 1955. Páginas inéditas del cancionero de Salamanca. Diputación de Salamanca, Salamanca.

Cortés Testillano T. 1991. Cancionero abulense. Caja de Ávila, Ávila.

Crespo Alcalde G. 1991. La montaña palentina. Tomo II La Lora. Merino Artes Gráficas, Palencia.

Crespo Alcalde G. 1991. La montaña palentina. Tomo IV Fuentes Carrionas y La Peña. Merino Artes Gráficas, Palencia.

Díaz J. 1980. Temas del cancionero en Castilla y León. Ayuntamiento de Valladolid, Valladolid.

Díaz J. 1982. Cancionero del norte de Palencia I. Institución Tello Téllez de Meneses-Diputación de Palencia, Palencia.

Díaz J. 1983. Cancionero de Palencia II. Institución Tello Téllez de Meneses-Diputación de Palencia, Palencia.

Díaz J., Delfín Val J. and Díaz de Viana L. 1981. Catálogo folklórico de la provincia de Valladolid. Vol. IV, cancionero musical primera parte. Institución Cultural Simancas, Valladolid.

Díaz J., Delfín Val J. and Díaz de Viana L. 1982. Catálogo folklórico de la provincia de Valladolid. Vol. IV, cancionero musical segunda parte. Institución Cultural Simancas, Valladolid.

Díaz de Viana L. 1993. Música y culturas. Eudema, Madrid.

Díaz de Viana L. and Manzano Alonso M. 1989. Cancionero popular de Castilla y León. Romances, canciones y danzas de tradición oral. Centro de Cultura Tradicional-Diputación de Salamanca, Salamanca.

Díaz de Viana L. and Manzano Alonso M. 1989. Cancionero popular de Castilla y León. Romances, canciones y danzas de tradición oral II. Centro de Cultura Tradicional-Diputación de Salamanca, Salamanca.

Domínguez Berrueta M. 1941. Del cancionero leonés. Diputación de León, León.

Fernández Núñez, M. 1931. Folklore leonés. Asilo de Huérfanos del S.C. de Jesús, Madrid.

García de Andrés P. and García de Andrés I. 2008. Cantos, rimas y juegos populares. Proyecto LIFE Tiermes, Soria.

Jiménez Juárez E. 1992. Cancionero español. Candeleda, Ávila. Manresa, Madrid.

Manzano Alonso M. 1991. Cancionero leonés Vol. II Tomo II. Diputación de León, León.

Manzano Alonso M. 1991. Cancionero leonés Vol. III Tomo I Canto religiosos, ciclo de navidad. Diputación de León, León.

Manzano Alonso M. 1992. Cancionero zamorano. Aeropuerto, Zamora.

Manzano Alonso M. 1998. Cancionero leonés Vol. I Tomo I Ronda y canciones. Diputación de León, León.

Manzano Alonso M. 1998. Cancionero leonés Vol. I Tomo II Tonadas y baile. Diputación de León, León.

Manzano Alonso M. 2001. Cancionero popular de Burgos: rondas y canciones, Tomo I. Diputación de Burgos, Burgos.

Manzano Alonso M. 2001. Cancionero popular de Burgos: tonadas de bailes danza, Tomo II. Diputación de Burgos, Burgos. Manzano Alonso M. 2003. Cancionero popular de Burgos: canciones infantiles, Tomo IV. Diputación de Burgos, Burgos.

Manzano Alonso M. 2003. Cancionero popular de Burgos: canciones del ciclo vital y anual, Tomo V. Diputación de Burgos, Burgos.

Marazuela Bornos A. 1997. Cancionero de Castilla. Endymión, Segovia.

Ricis G. 1981. Obra musical palentina del maestro Guzmán Ricis. Caja Palencia, Palencia.

Santos C., Delgado L.D. and Sanz I. 1992. Folk segoviano. I Rueda del año. Caja Segovia, Segovia.

Santos C., Delgado L.D. and Sanz I. 1998. Folk segoviano. I La jota segoviana. Caja Segovia, Segovia.

Sección Femenina. 1936-1975. Fichas de folklore. Archivo Provincial de Palencia, Palencia.

Tejero Cobos I. 1985. Cancionero popular de Segovia. Gráficas Ceyde, Segovia. 
Appendix 2. List of plants mentioned in the songs indicating family, Spanish common name, number of citations and status of presence in the region.

\begin{tabular}{|c|c|c|c|c|}
\hline Family & Specie & Name & Citatons & Status \\
\hline Amaranthaceae & Beta vulgaris $\mathrm{L}$. & remolacha & 3 & crop \\
\hline \multirow[t]{5}{*}{ Apiaceae } & Cuminum cyminum L. & comino & 2 & wild \\
\hline & Daucus carota L. & zanahoria & 2 & crop \\
\hline & Eryngium campestre L. & cardo corredor & 1 & wild \\
\hline & Petroselinum crispum (Miller) Fuss & perejil & 40 & crop \\
\hline & Pimpinella anisum $\mathrm{L}$. & anís & 3 & wild \\
\hline Araliaceae & Hedera helix L. & hiedra & 11 & wild \\
\hline \multirow[t]{2}{*}{ Arecaceae } & Phoenix dactylifera L. & palmera & 18 & absent \\
\hline & Roystonea regia (Kunth) O.F.Cook & palma real & 1 & absent \\
\hline Betulaceae & Corylus avellana L. & avellano & 45 & wild \\
\hline \multirow[t]{6}{*}{ Brassicaceae } & Brassica napus L. & nabo & 13 & crop \\
\hline & Brassica oleracea L. & berza & 1 & crop \\
\hline & Brassica oleracea L. & coliflor & 4 & crop \\
\hline & Brassica oleracea L. & repollo & 8 & crop \\
\hline & Erysimum cheiri (L.) Crantz & alhelí & 7 & decorative \\
\hline & Nasturtium officinalis R.Br. & berro & 7 & wild \\
\hline \multirow[t]{2}{*}{ Burseraceae } & Boswellia sacra Flueck. & incienso & 1 & absent \\
\hline & Commiphora myrrha (Nees) Engl. & mirra & 1 & absent \\
\hline Cannabaceae & Cannabis sativa L. & cáñamo & 3 & crop \\
\hline Caryophyllaceae & Dianthus caryophyllus L. & clavel & 173 & crop \\
\hline Cistaceae & Cistus spp. & jara & 1 & wild \\
\hline \multirow[t]{10}{*}{ Compositae } & Anthemis spp.; Matricaria spp. & manzanilla & 3 & wild \\
\hline & Bellis perennis $\mathrm{L}$. & margarita & 4 & wild \\
\hline & Calendula arvensis $\mathrm{L}$. & maravilla & 2 & wild \\
\hline & Carduus spp.; Cirsium spp. & cardo & 4 & wild \\
\hline & Cichorium endivia L. & escarola & 1 & crop \\
\hline & Cichorium intybus $\mathrm{L}$. & achicoria & 1 & wild \\
\hline & Cynara scolymus L. & alcachofa & 1 & crop \\
\hline & Dahlia x hortensis Guillanmin & dalia & 1 & decorative \\
\hline & Helichrysum stoechas (L.) Moench & siempreviva & 2 & wild \\
\hline & Lactuca sativa L. & lechuga & 28 & crop \\
\hline \multirow[t]{4}{*}{ Cucurbitaceae } & Citrullus lanatus (Thunb.) Matsumara \& Nakai & sandía & 6 & crop \\
\hline & Cucumis melo L. & melón & 18 & crop \\
\hline & Cucumis sativus L. & pepino & 11 & crop \\
\hline & Cucurbita pepo L. & calabaza & 39 & crop \\
\hline Cupressaceae & Cupressus sempervirens $\mathrm{L}$. & ciprés & 5 & decorative \\
\hline Cyperaceae & Scirpus lacustris L. & junco marino & 1 & wild \\
\hline Ericaceae & Arbutus unedo L. & madroño & 3 & wild \\
\hline \multirow[t]{6}{*}{ Fagaceae } & Castanea sativa Miller & castaño & 25 & wild \\
\hline & Quercus faginea Lam. & roble carrasco & 1 & wild \\
\hline & Quercus ilex L. & encina & 31 & wild \\
\hline & Quercus pyrenaica Willd. & rebollo & 2 & wild \\
\hline & Quercus spp. & bellota & 9 & wild \\
\hline & Quercus spp. & roble & 14 & wild \\
\hline Geraniaceae & Pelargonium zonale (L.) L’Hér. & geranio & 3 & decorative \\
\hline
\end{tabular}


Appendix 2. Continuation

\begin{tabular}{|c|c|c|c|c|}
\hline Family & Specie & Name & Citatons & Status \\
\hline \multirow[t]{2}{*}{ Iridaceae } & Crocus sativus L. & azafrán & 6 & crop \\
\hline & Iris spp. & lirio & 44 & wild \\
\hline Juglandaceae & Juglans regia $\mathrm{L}$. & nogal & 39 & crop \\
\hline Juncaceae & Juncus spp. & junco & 7 & wild \\
\hline \multirow[t]{7}{*}{ Lamiaceae } & Lavandula latifolia Medik. & espliego & 4 & wild \\
\hline & Melissa officinalis L. & melisa & 1 & wild \\
\hline & Mentha spicata L. & hierbabuena & 27 & crop \\
\hline & Ocimum basilicum L. & albahaca & 5 & absent \\
\hline & Rosmarinus officinalis L. & romero & 56 & decorative \\
\hline & Thymus mastichina L. & mejorana & 1 & wild \\
\hline & Thymus spp. & tomillo & 22 & wild \\
\hline \multirow[t]{2}{*}{ Lauraceae } & Cinnamomum aromaticum Nees & canela & 9 & absent \\
\hline & Laurus nobilis L. & laurel & 79 & wild \\
\hline \multirow[t]{18}{*}{ Leguminosae } & Arachis hypogaea L. & cacahuete & 1 & crop \\
\hline & Ceratonia siliqua L. & algarrobo & 2 & decorative \\
\hline & Cicer arietinum L. & garbanzo & 13 & crop \\
\hline & Cytisus scoparius (L.) Link & retama & 19 & wild \\
\hline & Genista florida L. & piorno & 1 & wild \\
\hline & Genista spp. & aulaga & 3 & wild \\
\hline & Lathyrus sativus L. & almorta & 6 & crop \\
\hline & Lens culinaris Medik. & lenteja & 7 & crop \\
\hline & Lupinus albus L. & altramuz & 1 & wild \\
\hline & Phaseolus vulgaris L. & judía & 10 & crop \\
\hline & Pisum sativum L. & guisante & 3 & crop \\
\hline & Tamarindus indica L. & tamarindo & 1 & absent \\
\hline & Trifolium spp. & trebol & 12 & wild \\
\hline & Ulex europaeus L. & tojo & 2 & wild \\
\hline & Vicia ervilla (L.) Willd. & yero & 1 & crop \\
\hline & Vicia faba L. & haba & 16 & crop \\
\hline & Vicia hirsuta (L.) S.F.Gray & arveja & 1 & wild \\
\hline & & legumbre & 1 & \\
\hline \multirow[t]{6}{*}{ Liliaceae } & Allium cepa L. & cebolla & 14 & crop \\
\hline & Allium porrum L. & puerro & 9 & crop \\
\hline & Allium sativum $\mathrm{L}$. & ajo & 24 & crop \\
\hline & Allium schoenoprasum L. & cebollino & 1 & crop \\
\hline & Asparagus officinalis L. & espárrago & 1 & crop \\
\hline & Lilium candidum L. & azucena & 47 & decorative \\
\hline Linaceae & Linum usitatissimum L. & lino & 27 & crop \\
\hline Lythraceae & Punica granatum L. & granado & 2 & crop \\
\hline \multirow[t]{3}{*}{ Malvaceae } & Gossypium hirsutum L. & algodón & 3 & absent \\
\hline & Malva sylvestris L. & malva & 5 & wild \\
\hline & Theobroma cacao L. & cacao & 14 & absent \\
\hline \multirow[t]{2}{*}{ Moraceae } & Ficus carica L. & higuera & 29 & crop \\
\hline & Morus spp. & morera & 4 & crop \\
\hline Myrtaceae & Syzygium aromaticum (L.) Merr. \& L.M.Perry & clavo & 4 & absent \\
\hline
\end{tabular}


Appendix 2. Continuation

\begin{tabular}{|c|c|c|c|c|}
\hline Family & Specie & Name & Citatons & Status \\
\hline \multirow[t]{3}{*}{ Oleaceae } & Fraxinus spp. & fresno & 2 & wild \\
\hline & Jasminum fruticans L. & jazmín & 9 & wild \\
\hline & Olea europaea L. & olivo & 114 & crop \\
\hline Papaveraceae & Papaver rhoeas L. & amapola & 9 & wild \\
\hline \multirow[t]{5}{*}{ Pinaceae } & Cedrus spp. & cedro & 2 & decorative \\
\hline & Pinus halepensis Miller & pino carrasco & 1 & crop \\
\hline & Pinus pinaster Aiton & pino resinero & 1 & crop \\
\hline & Pinus pinea $\mathrm{L}$. & pino piñonero & 4 & wild \\
\hline & Pinus spp. & pino & 68 & wild \\
\hline Piperaceae & Piper nigrum L. & pimienta & 13 & absent \\
\hline \multirow[t]{11}{*}{ Poaceae } & Arundo donax L. & caña & 5 & absent \\
\hline & Avena sativa L. & avena & 11 & crop \\
\hline & Cynodon dactylon (L.) Pers. & grama & 1 & wild \\
\hline & Hordeum vulgare $\mathrm{L}$. & cebada & 60 & crop \\
\hline & Oryza sativa L. & arroz & 11 & absent \\
\hline & Phyllostachys spp. & bambú & 2 & decorative \\
\hline & Secale cereale L. & centeno & 24 & crop \\
\hline & Stipa tenacissima Loefl. ex L. & esparto & 7 & wild \\
\hline & Triticum spp. & trigo & 142 & crop \\
\hline & Zea mays L. & maíz & 2 & crop \\
\hline & Primula acaulis L. & primavera & 1 & wild \\
\hline Primulaceae & Primula veris $\mathrm{L}$. & flor de San José & 2 & wild \\
\hline \multirow[t]{15}{*}{ Rosaceae } & Crataegus monogyna Jacq. & espino albar & 21 & wild \\
\hline & Cydonia oblonga Miller & membrillo & 3 & crop \\
\hline & Malus domestica Borkh. & manzano & 71 & crop \\
\hline & Malus sylvestris Miller & camueso & 3 & wild \\
\hline & Prunus armeniaca L. & albaricoquero & 2 & crop \\
\hline & Prunus avium L. & cerezo & 17 & crop \\
\hline & Prunus cerasus L. & guindo & 14 & crop \\
\hline & Prunus domestica L. & ciruelo & 14 & crop \\
\hline & Prunus dulcis (Miller) D.A.Webb & almendro & 24 & crop \\
\hline & Prunus persica (L.) Batsch & melocotonero & 7 & crop \\
\hline & Prunus spinosa L. & endrino & 7 & wild \\
\hline & Pyrus communis L. & peral & 50 & crop \\
\hline & Rosa gallica L. & rosa de Jericó & 1 & wild \\
\hline & Rosa spp. & rosal & 351 & decorative \\
\hline & Rubus ulmifolius Schott & zarzamora & 34 & wild \\
\hline Rubiaceae & Coffea arabica L. & café & 8 & absent \\
\hline \multirow[t]{5}{*}{ Rutaceae } & Citrus aurantiifolia (Christm.) Swingle & lima & 1 & absent \\
\hline & Citrus limon (L.) Burm. f. & Limonero & 63 & crop \\
\hline & Citrus sinensis (L.) Osbeck & naranjo & 64 & crop \\
\hline & Ruta graveolens L. & ruda & 1 & wild \\
\hline & Populus alba L. & chopo blanco & 4 & crop \\
\hline
\end{tabular}


Appendix 2. Continuation

\begin{tabular}{|c|c|c|c|c|}
\hline Family & Specie & Name & Citatons & Status \\
\hline \multirow[t]{5}{*}{ Salicaceae } & Populus spp. & chopo & 37 & crop \\
\hline & Salix babylonica L. & sauce Ilorón & 1 & decorative \\
\hline & Salix caprea L. & salguera & 1 & wild \\
\hline & Salix fragilis $\mathrm{L}$. & mimbrera & 4 & wild \\
\hline & Salix spp. & sauce & 1 & wild \\
\hline \multirow[t]{7}{*}{ Solanaceae } & Capsicum annuum L. & pimiento & 29 & crop \\
\hline & Capsicum frutescens $\mathrm{L}$. & guindilla & 5 & crop \\
\hline & Hyoscyamus niger L. & beleño & 2 & wild \\
\hline & Lycopersicon esculentum Miller & tomate & 12 & crop \\
\hline & Nicotiana tabacum L. & tabaco & 24 & crop \\
\hline & Solanum melongena L. & berenjena & 1 & crop \\
\hline & Solanum tuberosum L. & patata & 21 & crop \\
\hline Taxaceae & Taxus baccata L. & tejo & 1 & wild \\
\hline Theaceae & Camellia sinensis (L.) Kuntze & té & 1 & absent \\
\hline Ulmaceae & Ulmus minor Miller & olmo & 11 & wild \\
\hline Verbenaceae & Verbena officinalis L. & verbena & 3 & wild \\
\hline \multirow[t]{2}{*}{ Violaceae } & Viola spp. & violeta & 6 & wild \\
\hline & Viola x wittrockiana Gams & pensamiento & 2 & decorative \\
\hline Vitaceae & Vitis vinifera L. & vid & 197 & crop \\
\hline No defined & & helecho & 2 & wild \\
\hline
\end{tabular}

